\title{
MULTIPLE \\ REPRESENTATIONS \\ AND DYNAMIC \\ CONCEPTUAL \\ ANALYSIS \\ IN THE WILD
}

\section{MÚLTIPLAS REPRESENTAÇÕES E ANÁLISE CONCEPTUAL DINÂMICA EM DADOS NÃO CONTROLADOS}

\section{MÚLTIPLES REPRESENTACIONES Y ANÁLISIS CONCEPTUAL DINÁMICO EN DATOS NO CONTROLADOS}

Josie Helen Siman*

Nara Miranda de Figueiredo**

Universidade Estadual de Campinas

\begin{abstract}
Cognitive semantics has different research methods, such as introspection, corpora analysis, interaction analysis, and experiments. The analysis of "data in the wild" (corpora and interaction) is generally informed by theories, but rarely by the current landscape of experiments' findings on language and cognition. The goal of this paper is twofold: first, we want to highlight the possibility and importance of shortening the gap between theory, empirical evidence, and analysis of data in the wild in the study of cognition. Second, we suggest that resorting to the state of the art of empirical research about language and cognition allows for more flexible analyses, which may surpass the limits of current theories. In order to do that, we (i) provide a current overview of neuro and psycholinguistic findings about the grounding of concrete and abstract concepts, (ii) discuss how these findings can support linguistic data analysis, and (iii) emphasize trends toward multiple representation theories and dynamic systems.
\end{abstract}

KEYWORDS: Semantics. Cognition. Concepts. Dynamic. Multiple Representations.

RESUMO: A semântica cognitiva possui diferentes métodos de pesquisa, como introspecção, análise de corpora, análise de interações e experimentos. A análise de "dados produzidos em situações não-controladas" (corpora e interações) geralmente é baseada em teorias, mas raramente no cenário atual dos resultados de pesquisa experimental sobre linguagem e cognição. Este artigo tem dois objetivos, o primeiro é enfatizar a possibilidade e importância de diminuir a distância entre teoria, evidência empírica e análise de dados linguísticos no estudo da cognição. O segundo é sugerir que recorrer ao estado da arte de pesquisas empíricas sobre linguagem e cognição permite análises mais flexíveis, que podem superar os limites de teorias atuais. Para esse fim, (i) fornecemos

\footnotetext{
* Ph.D candidate in Psycholinguistics at University of Campinas (UNICAMP). E-mail: josiesiman@gmail.com, CNPq: $140359 / 2018-4$.

** Post-Doctoral researcher in philosophy of cognition at the Center of Logic and Epistemology (CLE) at the State University of Campinas (UNICAMP. E-mail: naramfigueiredo@gmail.com, CNPq:151055/2019-0
} 
uma visão geral atual de resultados de pesquisas neuro e psicolinguísticas sobre o "grounding" de conceitos concretos e abstratos, (ii) discutimos como esses resultados podem apoiar as análises de dados linguísticos e (iii) enfatizamos as tendências em direção a teorias de múltiplas representações e sistemas dinâmicos.

PALAVRAS-CHAVE: Semântica. Cognição. Conceitos. Dinâmica. Múltiplas representações.

RESUMEN: La semántica cognitiva tiene diversos métodos de investigación, como la introspección, el análisis de corpus, el análisis de interacciones y experimentos. El análisis de datos producidos en situaciones no controladas (corpus e interacciones) se basa generalmente en teorías, pero rara vez en el escenario actual de los resultados de la investigación experimental sobre lenguaje y cognición. Este artículo tiene dos objetivos, el primero es enfatizar la posibilidad e importancia de estrechar la brecha entre teoría, evidencia empírica y análisis de datos lingüísticos en el estudio de la cognición. El segundo es sugerir que recurrir al estado del arte de la investigación empírica sobre el lenguaje y la cognición permite un análisis más flexible, que puede superar los límites de las teorías actuales. Con ese fin, (i) proporcionamos una descripción actual de los resultados de la investigación neuro y psicolingüística sobre la "base" de conceptos concretos y abstractos, (ii) discutimos cómo estos resultados pueden apoyar el análisis de datos lingüísticos y (iii) destacamos las tendencias hacia las teorías de múltiples representaciones y sistemas dinámicos.

PALABRAS CLAVE: Semántica. Cognición. Conceptos. Dinámica. Múltiples representaciones.

\section{INTRODUCTION}

Most of cognitive semantics classic constructs are schematic, such as the notions of frames, scripts, conceptual metaphors, idealized cognitive models, etc (e.g., LAKOFF; JOHNSON, 1980; FILLMORE, 1982). These schemas are inferred from patterns in linguistic outputs (e.g., corpora, linguistic interaction, etc.) and introspection. These theoretical constructs are fixed and general abstractions. On the other hand, some data analysis in cognitive linguistics concentrates studies that are socially oriented (e.g., SEMINO et al., 2016; CAMERON et al., 2010; SIMAN, 2015). Traditionally, these linguistic data analyses apply cognitive semantics' theoretical constructs to data in the wild ${ }^{1}$ in order to make claims about people's conceptualizations of social or political issues or about meaning construction. It is sometimes the case that cognitive theories cannot account for all kinds of data in the wild, since this data is more variable than uncontextualized examples or generalizations over prototypical cases. cases.

In the neuro and psycholinguistic arena, scholars dispute the plausibility of theories and constructs from cognitive semantics, moreover, they inquire what else is known about the human conceptual system ${ }^{2}$. For instance, there are debates on the neuro and psychological plausibility of Conceptual Metaphors (cf. HOLYOAK; STAMENKOVIC, 2018; GIBBS, 2017; MCGLONE, 2007), on the plausibility and scope of the embodied cognition endeavor (cf. BARSALOU, 2020, 2016; LESHINSKAYA; CARAMAZZA, 2016), on the nature of the conceptual system (cf. BARSALOU, 2012), etc. In this paper, we suggest that there is no a priori reason why data analysis in cognitive linguistics studies cannot benefit from neuro and psycholinguistic findings and pursue a more interdisciplinary endeavor ${ }^{3}$. Experiments offer benefits that escape other approaches, such as the possibility of isolating particular target variables while controlling for confounders.

\footnotetext{
${ }^{1}$ Data in the wild is the data which is not controlled by an experimental paradigm and stimulus, which is language produced with little or no constraints by the researcher (e.g., corpora, interviews, etc). By contrast, experimental data are, generally speaking, measurements produced during an experiment which has controlled conditions.

${ }^{2}$ For Barsalou (2012, p. 239): “The human conceptual system contains people's knowledge about the world. Rather than containing holistic images of experience, the conceptual system represents components of experience, including knowledge about settings, objects, people, actions, events, mental states, properties, and relations. Componential knowledge in the conceptual system supports a wide variety of basic cognitive operations, including categorization, inference, the representation of propositions, and the productive creation of novel conceptualizations. In turn, these basic operations support the spectrum of complex cognitive activities, including high-level perception, attention, memory, language, thought, and socio-cultural cognition”. In short, as stated by Figueiredo and Siman (2020): "A theory of language needs to account for what kinds of knowledge we have in our conceptual system, how it is organized, how this knowledge interacts with symbols (if they do), and in what kind of contexts different parts of this web of knowledge is active".
}

${ }^{3}$ Experiments often dialogue with theories in Cognitive Linguistics (e.g. BERGEN, 2012), especially when they support the theories. The connection we want to establish with data analysis in cognitive linguistics is of a different kind: instead of using experiments to support the theory, we suggest that knowledge available in cognitive science can help to surpass theories' shortcomes. This might be needed for different reasons, as we address in this paper. 
In fact, understanding the cognitive science arena, especially the developments on the same subjects studied in cognitive linguistics, may allow for more flexible and empirically supported analyzes. Our specific goal is to suggest that the current landscape of findings in cognitive science can complement data analysis in cognitive linguistics by offering different plausible analytical possibilities. Moreover, in general, understanding the paradigm of experimental research in psycholinguistics and principles derived from neurolinguistic's literature can support deeper reflections on what may count as a cognitive pattern or a socially emergent pattern in some corpora.

The possibility of dialogue between cognitive linguistics and other cognitive sciences - beyond theory testing - is numerous. For instance, Bowdle and Gentner (2005) present an alternative metaphor theory to Conceptual Metaphor Theory (LAKOFF; JOHNSON, 1980) - a theory that is based on experiments' results and is being used and extended by Steen (2017).

To achieve our aim, timely, we present some recent findings and debates regarding the study of concrete and abstract concepts and the multiple representational and dynamic perspectives that emerge from this literature. Thus this paper is divided into the following sections: section 2 considers what is embodied about semantics - this is a review that highlights the importance of grounded cognition research to our field; section 3 refers to concrete and abstract concepts, focusing on recent insights about the nature of abstract concepts; section 4 is about what we can learn from these findings, in which we focus on how the notions of multiple representations, dynamics, and the principle that "neurons that fire together wire together" can inform decisions and discussions during the analysis of data in the wild; section 5 we make our final remarks and suggest (i) that linguists can also contribute to the characterization of concepts by further specifying its differences and (ii) that cognitive linguists can benefit from resorting to what is discussed in cognitive science. The literature and issues were selected with the purpose of illustrating how to bridge the gap between socially-oriented research (or data analyses focused on discussing social problems), empirical evidence, and theories.

\section{WHAT IS EMBODIED IN SEMANTICS?}

The claim that language is embodied is important for cognitive linguists, thus the discussion on embodiment will serve us as a guiding line in our discussion about multiple representationalism ${ }^{4}$ and dynamics ${ }^{5}$, which we argue are relevant themes for data analyses.

There are, in fact, many embodied approaches to cognition and many definitions of embodiment (LAKOFF; JOHNSON, 1999; BARSALOU, 1999, 2008; BERGEN, 2012; VARELA et al., 1991). Here we review the two most important claims about embodiment for cognitive linguistics. First, the claim that embodied experiences shape cognition (subsection 2.1), which is generally known by linguists, and second (subsection 2.2) the disputed claim that lower-level perception and action systems (e.g., olfactory, visual, gustatory, etc.) are involved in higher-order cognition, which is best known in other fields (e.g., psychology, neuroscience, etc.).

\subsection{EMBODIED EXPERIENCES SHAPE COGNITION}

One important claim from embodied theories is that embodied experiences shape cognition and language. This claim is illustrated by Lakoff and Johnson $(1980,1999)$, who argue, for example, that only because human bodies have "fronts" and "backs", they

\footnotetext{
${ }^{4}$ Roth (2010, p.32) states that: "a pervasive assumption in cognitive science is that the mind/brain employs and processes representations in the service of reasoning, thinking, categorizing, planning, problem-solving, understanding, imagining, remembering, and perceiving”. Representations are cognitive symbols that represent reality in its absence. The concept of "Dog" is composed of representations 9in our mind/brain) that allows us to think about dogs, recognize dogs, understand a text about dogs, etc. The multiple representation approach emphasizes the role of different types of experiences, as diverse as embodied and linguistic, in giving rise to our representation.

${ }^{5}$ Mitchell (2009, p.16) explains that: "[d]ynamical systems theory (or dynamics) concerns the description and prediction of systems that exhibit complex changing behavior at the macroscopic level, emerging from the collective actions of many interacting components". In the case of representations, Onnis and Spivey (2012, p.134) affirm that "various sources of information contribute to the co-emergence of dimensions of representation. Since each dimension of knowledge emerges gradually, multiple dimensions can provide statistical support to one another in highly interactive ways, and perfect correlations are not necessary". Dynamic approaches are an alternative to the computational metaphor of the mind: instead of describing representation and processing as fixed and linear, it assumes dynamic and probabilistic mental activities (SPIVEY, 2006; GIBBS, 2019).
} 
organize the world according to these concepts. "Fronts" are attributed to inanimate objects, such as TVs or refrigerators, in reference to the part of the object with which we interact: the front of the TV is the part that we watch, that we attend to as if the TV were a person. This "front" and "back" scheme would make no sense if we had other types of bodies, for example, if we were a ball. Nevertheless, it is not the case that we must have only embodied concepts, nor that all cultures must have the same embodied concepts (although there are some quasi-universal embodied concepts, cf. KÖVECSES et al., 2003). Lakoff and Johnson's theory simply acknowledges that we do have concepts shaped by our embodied experiences and that this should be part of our understanding of language and cognition.

There is massive evidence that our embodied experiences shape cognition and language (the review in this paper will showcase some of this evidence). Some examples will be discussed throughout this paper, especially in the "conceptual metaphor" section.

\subsection{LOWER-LEVEL PERCEPTION AND ACTION SYSTEMS ARE IMPLICATED IN HIGHER-ORDER COGNITION}

The claim that lower-level perception (e.g., olfactory, visual, gustatory, etc.) and action systems are involved in higher-order cognition is highly disputed in the cognitive sciences (e.g., LESHINSKAYA; CARAMAZZA; 2016; GOLDINGER et al., 2016; MAHON, 2015), but it is less so in cognitive semantics, which is generally focused on more abstract schemas. In this section, we will focus on briefly explaining the theories behind the claim that perception and action systems are part of what concepts are, contra the classic symbolic ${ }^{6}$ approaches that state that concepts are abstract representations (cf. BARSALOU, 2010, 2012). Evidence will be provided in the next section.

2.2.1 Grounding cognition

For Barsalou (2015, p. 3), “" [...] grounded' cognition acknowledges all the domains in which cognition is grounded and from which it emerges", i.e. sensorimotor systems, the physical environment, and the social environment. According to this view, understanding the conceptual system involves multiple experiential dimensions, and empirical research on grounded cognition, as we will show in section 3 , emphasizes the role of perceptual and action systems in meaning.

In explaining the conceptual system, the major premise of grounded cognition theories is that words get linked to the perception and action circuits or any low-level mechanism implicated in primarily situated experiences that they frequently correlate with, by Hebbian and anti-Hebbian principles, i.e. "neurons that fire together, wire together" and "neurons out of synch, delink", respectively (PULVERMÜLLER, 2013). The basic idea is that the learning and use of words frequently happen in the presence of their referents, which tend to co-occur with the activation of sensorimotor and affective systems. Thus, the meaning of a word is partially explained by these distributed systems that integrate our experiences with that word, even though a word meaning cannot be reduced to its sensorimotor and affective components (BARSALOU, 2016), as we will discuss in the following sections.

The emphasis on grounding concepts on experience does not imply that grounded approaches are completely incompatible with classic symbolic (e.g., FODOR, 1975) or with statistical/dynamic systems ${ }^{7}$ (e.g., SPIVEY, 2006) approaches to cognition. For Barsalou (2015, p.1), "[...] a concept is a dynamical distributed system in the brain that represents a category in the environment or experience, and that controls interactions with the category's instances (e.g., the concept of bicycle represents and controls interactions with bicycles)". Concepts are dynamic because they may change throughout life (e.g., think of what "love" is for a child, a teenager, or an adult), not to mention throughout history, cultures, and contexts; and concepts are distributed because they engage different systems in the brain (sensorimotor, vision, auditory, etc.).

\footnotetext{
${ }^{6}$ Classic symbolic approaches are theories that emerged in the 1950 s, which understand cognition through the "computer metaphor". From this perspective, the mind is supposed to abstractly represent the world and perform computational operations on it. The best-known approach to language from this perspective is the Generative Grammar (CHOMSKY, 1957).

${ }^{7}$ Statistical approaches to cognition emphasize the "Bayesian" aspect of the mind in learning from experiential distributed patterns. Dynamic approaches, based on the dynamic systems theories, emphasize the roles that networks of knowledge and weighted frequency distribution play in the mind. Some of these approaches are non-symbolic; they reject the "computational metaphor of the mind", substituting it for the "dynamic systems metaphor of the mind" (e.g., SPIVEY, 2006). The grounded cognition approach is very consistent with the dynamic systems approach to cognition. Concepts, in this case, are distributed neuronal assemblies that are partially and probabilistically activated (instead of being discrete entities, as the classic symbolic approach would claim).
} 
As we mentioned above, in spite of that, grounded cognition can also be compatible with classic symbolic approaches, since it is possible to consider that the dynamical distributed system has imagetic content to which symbols are bounded, establishing a typetoken mapping (BARSALOU, 2012). Moreover, symbol combination would involve the manipulation and integration of image components to construct structured images that implement complex symbolic propositions (ibidem). In neurological terms, Pulvermüller (2012, p. 90) considers the relationship between words and perception and action circuits to be realized in a distributed manner:

\begin{abstract}
The binding of these features [features of an object that have inputs from different modalities, e.g. shape, smell, etc.] into one coherent representation could, in principle, be instantiated by pathways linking the sensory information from different modalities to the same "central" neuron(s). These critical cells should then be housed in areas where inputs from many sensory fields converge (Damasio, 1989). It is, however, not necessary to assume a single central convergence area, or a local (set of) cardinal cell(s). The neuroanatomical connection pattern of the cortex indicates that links between primary cortices are provided through more than one route, involving several non-primary areas. There is, therefore, no need for assuming single specialized areas or neurons for binding of the information defining engrams. Together with the neuroscientific knowledge about cortico-cortical connections, the correlation principle suggests that it is the entire ensemble of cortical cells frequently activated together when certain objects are being perceived, or when specific actions are being carried out, that develops into the functional unit realizing the object or action at the neuronal level.
\end{abstract}

Thus, some grounded approaches are symbolic, whereas others are non-symbolic. The bone of contention of grounded approaches is that perceptual and action systems are involved in meaning, even if not in all contexts (BARSALOU, 2016). In short, grounded approaches claim that conceptual processing involves a hierarchy of interconnected and distributed functional systems, which get established, for instance, when language processes frequently correlate with perception and action systems, strengthening their neuronal connection. These neural circuits may include modality-specific, multimodal areas, and amodal or polymodal ${ }^{8}$ hub regions (TOMASELLO et al., 2017; PULVERMULLER, 2005, 2018).

Since the classic approach to cognition is centered in the premise of symbols being amodal, i.e. disconnected from sensorimotor and affective systems, much of the grounded cognition research has been dedicated to demonstrating that concepts are grounded in sensorimotor systems and that processing conceptual information recruits these systems, i.e. sensorimotor information is not epiphenomenal to conceptual processing; it is not a "spill-over" effect. In the next sections, we present some of the empirical research which has provided evidence for the claim that concepts are grounded in sensorimotor systems and other types of experiential information.

\title{
3 WHAT ARE CONCRETE AND ABSTRACT CONCEPTS?
}

In this section, we will present neuro and psycholinguistic evidence that concepts are grounded in perception and action systems. We discuss the embodiment of concrete concepts (subsection 3.1), abstract concepts (subsection 3.2), and the polemics about the relationship between metaphors and concepts (subsection 3.2.1), which are relevant subjects in the cognitive sciences.

\subsection{CONCRETE CONCEPTS}

Concrete concepts are generally defined as concepts related to referents that are (often) physically and spatially constrained and experienced by our five senses (cf. BARSALOU; WIEMER-HASTINGS, 2005). Research in grounded cognition has come a long way into finding evidence that processing concrete concepts recruits partial systems that are active when we experience the same referent in the world. For concrete concepts, research focuses on showing that sensorimotor systems in the brain are not only active during passive recognition of words (and other tasks), but it is active at very early stages of processing, which should indicate that these systems are recruited for language processing (i.e. their activation is not an epiphenomenon).

\footnotetext{
${ }^{8}$ Modal systems are systems like the sensorimotor, visual, gustatory, olfactory, motor, etc (i.e. systems involved in perception and action). Amodal system is the name given to abstract systems (e.g. feature-based systems used in computational theories about cognition). Polymodal system is a novel name given to amodal systems, in recognition of the fact that no semantic knowledge is amodal: they allude to some modality. Multimodal system is generally the name given to the convergence of different modal information, such as visual (e.g. color) and olfactory (i.e. smell).
} 
The evidence covers the activation of somatotopic regions of the brain when processing action related-words, for instance, feetrelated action words, as "kick", should activate feet-related areas in the brain, instead of hand-related areas (PULVERMÜLLER, 2005; PULVERMÜLLER; FADIGA, 2010; PULVERMÜLLER, 2018; GARCÍA; IBÁÑEZ, 2016).

Other sensorial systems are also empirically explored. Research shows that words that have high olfactory associations (e.g., cinnamon) activate the primary olfactory cortex (GONZÁLEZ et al., 2006). Also, gustatory-related words (e.g., salt) activate the primary and secondary gustatory cortices (BARROS-LOSCERTALES et al., 2011). In addition to that, sound-related words (e.g., telephone) elicit high activation of the superior temporal cortex (KIEFER et al., 2008). Some words strongly evoke visual properties, be it color or shape, and activate occipitotemporal visual processing regions (MARTIN; CHAO, 2001; MARTIN, 2007; AMSEL et al., 2014; DEL PRADO MARTIN et al., 2006).

In short, studies show evidence that sensorimotor systems are recruited for processing words in all modalities (gustatory, auditory, visual, olfactory, sensorimotor). More than that, there is support for the claim that the activation of sensorimotor systems is not an epiphenomenon since these systems are active at very early stages of language processing (cf. KIEFER et al., 2008; KIEFER, et al., 2011; GARCÍA et al., 2019). This is not to say that sensorimotor systems need to be recruited at all times: there are contextual variations even for the so-called "essential features" of any concept (BARSALOU, 2016). This also does not mean that sensorimotor systems are indispensable, or that the absence/compromise of sensorimotor systems (e.g., by disease) will necessarily impair conceptual processing (even though it happens in some cases). There are compensatory mechanisms involved in the conceptual organization (ibidem). Thus, grounding concepts is something that the mind does, and it explains our rich and variate capacity of understanding the language.

There is increasing support in the cognitive sciences for the idea that we use sensorimotor information for forming concepts when we have access to it (ANTONUTTI; ALT, 2011). However, our conceptual knowledge should not be restricted to sensorimotor information: humans mature and are able to associate information (e.g. through linguistic inputs and co-occurrence of information) to develop concepts further, which emphasizes the importance of language itself in the grounding of concepts (BORGHI et al., 2018; DESAI et al., 2018; FIGUEIREDO; SIMAN, 2020).

\subsection{ABSTRACT CONCEPTS}

Establishing the grounding of concrete concepts has been shown to be possible and is an important topic in the literature. Abstract concepts, on the other hand, have a history of being a challenge to many theories (BARSALOU, 2016; GALETZKA, 2017). For earlier theories that accepted the role of sensorimotor systems for grounding concrete concepts, abstract concepts were assumed to be too "abstract", forcefully symbolic (PAIVIO, 1986). But every day more, grounded cognition research is gathering evidence for the grounding of abstract concepts, as this section will show.

In this section, we will first present the original claim that abstract concepts were mostly metaphorical. Then, we will present some recent research on the grounded aspects of abstract concepts.

\subsubsection{Abstract concepts and Conceptual Metaphors}

Conceptual Metaphors (LAKOFF; JOHNSON, 1980) are metaphors that are entrenched in culture and, as claimed by Lakoff and Johnson, in thought. They are systems of cross-domain mappings that are assumed to be automatically and unconsciously activated when we process metaphors that are based on these systems. There are thousands (LAKOFF, 2012) of systematic schemas ("in the conceptual system") that underlie everyday metaphoric expressions ("in linguistic outputs"). For example, the expressions "This relationship is going nowhere", "We are spinning our wheels", "Our marriage is on the rocks" are all instantiations of the conceptual metaphor LOVE IS A JOURNEY, which comprises cross-domain mappings as LOVERS ARE TRAVELLERS, RELATIONSHIP IS A VEHICLE, DIFFICULTIES (IN THE RELATIONSHIP) ARE OBSTACLES (IN THE JOURNEY) and so on (cf. LAKOFF, 2008).

One important attempt at grounding abstract concepts was put forward by scholars who study conceptual metaphors (LAKOFF; JOHNSON, 1980; KOVECSES, 2000; GALLESE; LAKOFF, 2005). The basic idea was to ground abstract concepts indirectly (via metaphor) on concrete concepts. From this point of view, it was proposed what later came to be known as the "strong hypothesis" 
regarding what abstract concepts were: abstract concepts were almost entirely composed of conceptual metaphors. Conceptual metaphors were assumed to be fixed and enduring projections from more familiar, structured, and concrete domains of knowledge to less familiar, less structured, and more abstract domains ${ }^{9}$. As Sauciuc (2013, p. 244) synthesizes:

CMT [Conceptual Metaphor Theory] posits that only a few basic domains and concrete concepts emerge directly from bodily experience: e.g., spatial orientation, containment, force, and temperature. All abstract concepts - including emotion concepts - are indirectly grounded in these basic domains by sets of enduring metaphorical mappings, whose purpose is to assist understanding the more abstract concepts in terms of the more concrete ones. (KÖVECSES, 2000, p. 4)

The strong view that metaphors were almost entirely responsible for our abstract concepts has been extensively criticized (MURPHY, 1996; SAUCIUC, 2013; BUNDGAARD, 2013, 2019). The "weak hypothesis", on the other hand, states that abstract concepts were very poor in content, presenting only some interoceptive knowledge and some schemas, for instance, the concept of "love" has the slots of "a lover, a beloved, a love relationship, and not much more" (GALLESE; LAKOFF, 2005, p. 470), and these slots would be the basis which would get mapped out in the metaphoric cross-domain correspondences. What enriched these poor abstract concepts were Conceptual Metaphors: thus, the concept of "love" would be mostly made out of many conceptual metaphors (e.g., LOVE IS A JOURNEY; LOVE IS WAR; LOVE IS A GAME; etc). The weak hypothesis is also problematic:

[...] it has been objected that not all abstract concepts can be explained by recurring to metaphorical mapping and that the mechanism of metaphorical mapping is not sufficient to account for the acquisition of abstract concepts. Thus, CMT, although quite influential, seems to provide only a partial solution to the problem of abstract concepts. (CUCCIO; GALLESE, 2018)

And:

with regards to the non-metaphorical structure or content of concepts, it appears to be much richer than what Lakoff and Johnson have suggested; once you take away the metaphors through which we think of, say, "Love," we have, as Sauciuc (2013) and Barsalou and Wiemer-Hastings (2005) show, all those situations where this emotion is likely to be elicited, all those things we do (with each other) when in that state, the things we think, the things we feel, the way our bodies respond, and so on and so forth. (BUNDGAARD, 2019)

Thus, recent literature suggests that abstract concepts have a rich knowledge system. Metaphors just add knowledge to this already rich system (be it abstract or concrete, since concrete concepts can also imply entrenched conceptual metaphors, e.g., COMPUTERS ARE PERSONS: "My PC does not want to work. It is stubborn.”). What exactly this metaphoric knowledge that integrates concepts might be is a disputed subject (BOWDLE; GENTNER, 2005; GLUCKSBERG, 2003; GIBBS, 2017; STEEN, 2017).

In spite of the disputes over metaphors, and considering that the role of metaphors for abstract concepts is likely to be smaller than previously suggested ${ }^{10}$ (CUCCIO; GALEESE, 2018; BUNDGAARD, 2019; see next section), the metaphoric basis of some abstract concepts is still a major research topic and one which has important evidence. A very important work shows how metaphors shape our abstract concepts is Gentner and Boroditsky's (2001) time experiment. The experiment shows that English speakers' concept of time includes schemas for ego-moving metaphor (e.g., "we are approaching Christmas") and the time moving metaphor (e.g., "Christmas is coming"), and having to switch between the two schemas to answer questions produces an increase in time responses. It is important to notice that this finding does not imply that our understanding of the concept of time is completely metaphoric,

\footnotetext{
${ }^{9}$ The definitions of metaphors changed with time (see LAKOFF, 2008; GIBBS, 2017).

${ }^{10}$ Lakoffs (2008) and Grady's (1997) claim that the connection between AFFECTION and WARMTH is a primary metaphor is also challenged by the recent psycholinguistic literature: "while some effects appear to support metaphor theories by showing an overlap of insular cortex activation for social and physical warmth (e.g., INAGAKI; EISENBERGER, 2013), other research has clarified that it is subjective temperature changes that lead to insular cortex activation (CRAIG et al., 2000) while many social and thermoregulatory effects already happen at much lower levels, like at the level of the medial pre-optic area of the hypothalamus (BOULANT, 2000). The more appropriate way to conceptualize the underlying organization of neural systems related to social thermoregulation is as a "hierarchical prediction machine", where higher order areas (e.g., those related to insular cortex activation and monitoring social contact) help foster more efficient activity at lower levels (e.g., regulating temperature and social contact at the hypothalamic level [...]" (IJZERMEN et al., 2018).
} 
but only that metaphors are a part of our systematic knowledge about time and other concepts, and that these schemas are used for reasoning sometimes (for more experiments that support the claim that metaphors are a part of our conceptual system, see: GIBBS, 2017).

\subsubsection{The non-metaphorical grounding of abstract concepts}

If abstract concepts are not mostly metaphoric, what are they, what are they grounded in, and why do they seem to be more "difficult" to characterize and study?

Following Davis et al. (2020), let us consider the difference between our understanding of the concepts "toast" and "sharing". While "toast" involves the relationship between bread, butter, heat, and eating; "sharing", involves the relationship between two or more participants and an "entity" being shared. While the slot (FRAME INDEX, 2021)variations involved in the "toast" instance are of little relevance (brand of butter, exact temperature, etc), the slot variations of "sharing" can be as ample as food, custody, house, etc. And it is not only the case that the slots vary, but the whole action-related schemas (e.g., of sharing food versus sharing a house) vary widely. There are also more subtle differences: "sharing" implies "consent" (e.g., if someone takes part of your food with your consent, you are sharing; if you do not know or allow them to take it, then, it is not sharing), as Davis et al. notice. So while concrete concepts tend to involve objects that we can engage with our senses, abstract concepts are not concepts that do not have a perceptual or action component -as we will show next- but are concepts that nest intricate conditions. For instance, "sharing" needs to be "consented" and "justice" needs to be relative to some variable "cultural standard". Abstract concepts' slots vary more widely in relation to its content, as well as in relation to its time-course ("sharing a car" is an activity that can be allocated in any time constraints: now, i.e. we are both in the car; or unconstrained, i.e. we take turns in using the same car for an indeterminate time), and the variation in time constraints matters for its meaning.

Thus, as compared to concrete concepts (which tend to be more physically and spatially constrained, and experienced by our five senses, as already mentioned), abstract concepts are:

a. more complex: they typically "capture complex configurations of physical and mental events"; b. more detached from physical experience, although they might also activate perceptual modalities and interoceptive experience; c. more variable, both across and within participants, in different situations. (BORGHI et al., 2018, p. 121)

Recent research has focused on establishing abstract concept's multivariate character, by elucidating their interoceptive, affective, social, sensory, and motor-related properties, along with verbal associations (HARPAINTNER et al., 2018) and introspection/metacognition (BORGHI et al., 2018; SHEA, 2018).

The grounding of numeric concepts on experience, for example, has been observed in two ways. Finger counting habits are associated with numeric concepts, which is considered as the grounding of numbers in the primary motor cortex (DESAI et al., 2018). Moreover, there is evidence that numeric concepts are associated with a left-to-right coordinate of space (or a "mental line of numbers"), which is called the Spatial-Numerical Association of Response Codes (SNARC) effect. This phenomenon testifies for an important perceptual and experimental bias regarding numbers - a conceptual category that is often regarded as a purely symbolic construct. Recent discussions propose that the SNARC effect is not universal (CIPORA et al., 2019), that is, only some people make the associations between numbers and a mental line.

Harpaintner et al. (2020) show that the processing of motor abstract words (e.g., Fitness) specifically activates frontal and parietal motor areas, whereas processing of visual abstract words (e.g., Beauty) elicits higher activity in temporo-occipital visual areas, but at a more lenient statistical threshold, which might be explained by the fact that these concepts are underspecified without a context. Interestingly, the concept of beauty can be applied to other modalities (e.g., a beautiful voice/ melody) and to abstract entities (e.g., a beautiful poem, idea, plan), even though it is predominantly associated with visual stimulus. Thus, further testing of the grounding of the concept "beauty" could involve the use of different contexts. 
Behavioral studies also support the claim that abstract concepts are grounded. For instance, Glenberg et al. (2008) studied the abstract notion of "transfer". They asked participants to read sentences implying movement toward and away from oneself, for example, "Anna delegates the responsibilities to you" is considered as implying a movement toward oneself, while "You delegate the responsibilities to Anna" is considered as a movement away from oneself. Participants then judged the sensibility of sentences by responding in the direction that either matched or mismatched the direction implied by the sentence. The major finding was that the participant's judgments were faster when response direction and sentence direction matched. Thus, it can be argued that understanding "transfer" recruits sensorimotor systems.

As studies focus on the grounding of action words by looking for effects mainly in the motor cortex, the grounding of sensorial words in the sensory cortices, the grounding of emotions mainly in the amygdala, recent research is still establishing what other categories of abstract words can be distinguished and grounded. Some of the word categories suggested so far are numeric (e.g., one, two), emotion (e.g., love), social (e.g., share/ democracy), aesthetic (e.g., beauty), moral (e.g., wrong), mental (e.g., think), spiritual (e.g., faith), science (e.g., gravity) and functional (e.g., negation, causation). But it is likely that these categories can be further broken down and rearranged to showcase different properties of the concepts. So much so that it has been proposed that concepts should be represented in a high-dimensional space (with shared properties making up for shorter distances between concepts) and that they are continuous or graded (DESAI et al., 2018; BORGHI et al., 2018; DAVIS et al., 2020).

Regarding the difference between concrete and abstract concepts, the continuity between them suggests that sensorimotor information is more strongly presented in and is of central relevance to concrete concepts (e.g., hammer), as compared to abstract concepts (e.g., think), and intermediate cases (e.g., fitness). Therefore, considering statistical approaches to the brain (e.g., SPIVEY, 2006), it would be expected that the weight of different properties of a concept (e.g., sensorimotor information) is differently distributed in a continuum. For this reason, Barsalou et al. (2018) suggest that we move on from the traditional binary distinction between concrete and abstract concepts.

\subsection{MULTIPLE REPRESENTATIONS AND DYNAMICS}

In this paper, we focused mainly on the grounding of concrete and abstract concepts, because this is an important subject for embodied cognitive linguistics. But, as we all know, concepts cannot be reduced to sensorimotor systems. Multiple representations' accounts of concepts admit that concepts comprise many different types of information: sensorimotor, linguistic, and affective (BORGHI et al., 2018).

This information may be organized in different ways, some of them being predominant for some concepts and not for others. Concepts are acquired or further developed when we physically interact with its referent, but not only (or not always): we may acquire or develop or reorganize concepts when we think about them (metacognitively), when someone explains its meaning to us (direct use of language), by inferring meaning from multiple contextual uses (language/statistics), or by indirectly using linguistics cues (e.g., syntax). This is why information may involve different representational patterns.

Besides, by admitting language dynamics, as we mentioned in section 2.2.1, along with multiple representations acquired through experience, we can understand how meaning is essentially contextual and individual. Even though meaning is essentially individual, common patterns will emerge because of shared biological, cognitive, psychological, and socio-cultural experiences. So meaning may overlap in society without being precisely the same, and meaning may differ as much as biological, cognitive, psychological, and socio-cultural experiences can be different. This is important to have in mind for our discussions in the next section.

\section{CONCEPTUAL KNOWLEDGE AND DATA ANALYSES}

There are many interesting topics to consider regarding the recent discussion about concepts that may complement data analyses in cognitive linguistics. In the next sections, we highlight and discuss some of them. 


\subsection{MULTIPLE REPRESENTATIONS OF CONCEPTS}

Traditionally, theories in cognitive semantics defend categorical claims. An example of this would be to claim that all concepts are embodied or all processing recruits sensorimotor systems. As a consequence, experiments' results should either support this claim or not and if they do not, then sensorimotor systems would be deemed irrelevant for language processing. But cognition is far more complex than that, and what results show is that sensorimotor systems are recruited under some conditions and not others (as any other aspect of concepts, even those that, in traditional feature-based analysis, are considered "essential" features - see Barsalou, 2016). In fact, the general variability of the conceptual systems is being discussed by many scholars from different approaches to cognition (BORGHI et al., 2018; CUCCIO; GALLESE, 2018). In this sense, as we showed in the previous sections, concepts carry not only sensorimotor information but also information derived from linguistic input and introspection.

These findings are important for us for many reasons: 1) as explained in previous sections, we can move away from the claim that abstract concepts are all metaphoric - metaphors are only a part of of our conceptual system; 2) with an enriched view of concepts, we may start discussing concepts, when we find it relevant, instead of exclusively applying traditional abstract level constructs (e.g., frames, metaphors, MCIs, etc) in our analyses; 3) we may choose to emphasize multiple representations, supported by multiple theories and findings (such as the findings presented in the previous sections, and many other that fall in the scope of evidencebased cognitive sciences), instead of only making analyses that fall into the scope of cognitive semantics' theories. The important point is to realize that, when we are analyzing data in the wild, we are inquiring about conceptualizations, which relate to our conceptual system (its content and its organization). However, our scientific understanding of the conceptual system is disputed and updated in cognitive sciences. Thus, going beyond cognitive semantic theories to incorporate recent experimental findings might be a way to overcome challenges encountered in analyses of complex data in the wild.

This multi-representational perspective should be relevant even to improve metaphor theories and analyzes, but this is an ongoing project. For example, Steen's Deliberate Metaphor Theory (2017) allows for multiple representations ${ }^{11}$, in the sense that the author claims that some metaphors are represented as a lexical entry and others as cross-domain mappings. Gibbs (in personal communication, 2020) admits that Glucksberg's findings (2003) could be considered an attractor in his dynamic systems perspective. Thus, we can infer that determining which metaphor theory is right is not mandatory to advancing our understanding of them, but exploring what metaphors have which profile, and under what conditions metaphors are processed one way or another, is.

\subsection{DYNAMIC COGNITION}

The idea that cognition is dynamic has been around in cognitive semantics (e.g., CAMERON et al., 2010; CROFT; CRUISE, 2004) and the related discussion of whether the mind is symbolic or not is ongoing in cognitive science (SPIVEY, 2006; BARSALOU, 2012; DI PAOLO et al., 2018). There are many reasons why considering the dynamicity of concepts is important for linguistic data analyses.

First, we can understand that there might not be one "right" level of generalization/abstraction that accounts for all concepts or metaphors, all people, and all situations of use. And that we do not have to be committed to one single level of description because of what is found in some theoretical formulation. Thus, data analysis can best mirror their data (but they must also be especially careful with what generalizations about society or cognition their data may support). Second, and most importantly, with such a dynamic approach to cognition - and to social problems, in the case of data analyses - we must be careful with categorical conclusions that we derive from our analysis. For example, in the case of metaphors, scholars sometimes claim that some metaphor use is good or bad for some reason. Instead, we must focus on making explicit to what groups of people a metaphor might be either good or bad

\footnotetext{
${ }^{11}$ As we have highlighted in the section about concrete and abstract concepts, recent work in cognitive sciences highlight the multiple representational aspects of our conceptual system, meaning that the information in our conceptual system is derived from sensorimotor and affective systems, metacognition, and linguistic input, among others. This line of reasoning implies that there is no single mechanism and source of information from which concepts are built. The same line of reasoning could be applied to other cognitive phenomena: for instance, instead of promoting an invariance (BORTFELD; MCGLONE, 2001) principle to characterize metaphors (or any other cognitive phenomenon), an alternative analysis would rely on multiple representations (e.g. BOWDLE; GENTNER, 2005; STEEN, 2017).
} 
if this is really the case (LANE et al., 2013; BEHUNIAK, 2011; GEORGE; WHITEHOUSE, 2014; NGATCHA-RIBERT, 2004; SIMAN, 2019). We must also be aware that, since meaning-making is dynamic and based on individual experiences, the same concept might be bad for some people and good for others; bad or good in some context, and irrelevant in others. We must be aware of what claims we intend to make, and if our data really supports and justifies that claim (as opposed to making a claim supported by some theory that is categorical in its premises, instead of dynamic).

A typical example of a categorical claim that should be avoided is the claim that "war metaphors" should be substituted by other less negative - metaphor (see discussion in SIMAN, 2019; FLUSBERG et al., 2018). First, "war metaphor" is a generic group, and we might find different profiles of metaphors there (e.g., some metaphors might be more conventional than others, and metaphors might be used to characterize different aspects of the same experience). Second, as we know, people have different experiences with the rhetoric of war: some people like it and benefit from this metaphor, whereas others do not (SEMINO et al., 2016). Lastly, this kind of categorical claim is supported by the Conceptual Metaphor Theory (LAKOFF; JOHNSON, 1980), which treats metaphors as cross-domain fixed patterns (LAKOFF, 2008). In considering a dynamic perspective, metaphors in context emerge from people's situated needs and perspectives, and this goes beyond classic cross-domain mappings theorizing (GIBBS, 2019). Moreover, whatever meaning the public might derive from metaphors in use is a product of hundreds of different constraints (e.g., task, attention, previous experiences with that metaphor, position, and function of that metaphor in the discourse, etc.) that, once again, goes beyond fixed cross-domain mappings. Thus, if scholars want to defend that some metaphor has a negative impact on society, they must account for all of the factors involved in metaphor processing and meaning.

\subsection{WHAT IS SOCIAL AND WHAT IS COGNITIVE IN SOME DATA?}

Often, scholars might have to decide if the pattern they see in their data refers to something which is social or cognitive. That is, if the pattern implies a cognitive construct or if the pattern is emergent from systematic factors experienced by people.

For instance, in studying the discourse of Alzheimer's disease (AD), Van Gorp and Vercruysse (2012) encountered what they named the "faith in science" frame ${ }^{12}$. This frame is realized by different linguistic expressions, variants of the same idea: the trust that science will find the cure for Alzheimer's (e.g., "I have faith that scientists will find the cure", "I hope science will find the cure"). Instantiations of this frame were found in Siman's (2015) interviews with specialists and family members of people with AD, and Martins' (2019) journalistic corpus research. But the question is: is "faith in science" a frame on its own or is it a mere combination of two concepts: "faith" and "science"? How do segments of discourse reflect cognition?

This is a question that the literature in cognitive linguistics will not answer. First, as we mentioned, theories tend to focus on aspects of concepts that are widely shared, not so much on sub-groups of the population. Second, theories rely on experiments to access their plausibility. That is why we need to be well-informed about what is currently known about cognition to make better decisions. Besides, by understanding the methods in neuro and psycholinguistics, we are better equipped to make finer distinctions about data in the wild and conclusions that can be justified on empirical grounds.

\footnotetext{
${ }^{12}$ Frames, one of the central constructs in cognitive semantics, are a schematic kind of knowledge about events, situations, entities, relationships, etc. represented by elements (which are structural components that are fixed) and slots (for variable information) in a relational structure. Frames can be considered transduced patterns from recurrent experiences, for example, the experience of "buying", frequently involves central elements such as a buyer, a seller, a product, some payment form, a price, etc. Even if the actual "seller" is a different entity every time (i.e. the slots are filled differently, for instance, as "John", "Mary", or "Amazon Company"), the central elements of "buying" are always implied. Frames can also be transduced from patterns in grammar: every time one uses the verb "to buy", the same elements are either present or implied in the sentence (e.g. "she bought a dress for 10 dollars": she is the buyer, a dress is the product, for 10 dollars is the price - and other elements are implied, so much that you are correct to ask "Did she pay with her credit card? Who sold her the dress?"). Fillmore (1982, p.111) used the term "frame" in a very broad sense: "By the term 'frame' I have in mind any systems of concepts related in such a way that to understand any one of them you have to understand the whole structure in which it fits; when one of the things in such a structure is introduced into the text, or into a conversation, all of the others are automatically made available."
} 
People could process "faith in science" as a frame (or as an entry to an organized concept/idiom, much like what would be expected from the compound expression "Alzheimer's disease" ${ }^{13}$ ) or as a combination of two different frames, "faith" and "science". Processing may vary from person to person and from situation to situation. One way to establish the likelihood that "faith in science" is a frame is to analyze how often that subgroup of society expresses/reads about this idea. All in all, the frequent occurrence of "faith in science" might just emerge because of external pressures (i.e. the previous success of science in curing other diseases; the despair caused by the new incurable disease): if this is so, "faith in science" is not a frame. If we have reasons to believe that part of a population does use these concepts together frequently, then, it might be a frame (in a broad sense) for that population, even if not for ourselves (or for most people).

The rationale is based on the Hebbian principle that "neurons that fire together wire together" (presented in section 2). At this point, even if we are able to verify that some part of the population do in fact construct the idea of "faith in science" frequently, we cannot guarantee that this is a frame. As always, developments in interdisciplinary empirical research will improve our analyses. A way out of the difficult decisions we are faced with when working with data in the wild is to make claims about language as a social product (for example patterns of use that emerge from several social factors) and not as a cognitive frame with specific associations. Or, as Steen (2017) does for metaphor analysis, we can affirm that this is "possibly" a frame, but experiments are needed to confirm it. In all cases, we believe that it is important (1) to have the support of the literature on psycholinguistics and cognitive neuroscience for enriching our analysis and theoretical distinctions and (2) to be able to point out what findings are problematic in the context of our linguistic data analysis in the wild. This is opposed to establishing ad-hoc definitions (e.g., SEMINO et al., 2016; SIMAN, 2019) or eventually ignoring some inconsistency in the analysis.

\section{FINAL CONSIDERATIONS}

In Cognitive Semantics, we usually focus more on understanding the structures of concepts (e.g., the frames), but much less on understanding more general characteristics of concepts (e.g., BARSALOU, 2020). Two of the reasons why there has been little discussion on the nature of concepts are that (i) cognitive scientists believed abstract concepts were entirely symbolic (PAIVIO, 1986); and (ii) Lakoff and Johnson (1980) proposed that abstract concepts were almost entirely metaphoric (see also: BUNDGAARD, 2019). Nevertheless, recent discussions, as we have presented in this paper, show otherwise - that abstract concepts are not entirely symbolic or almost entirely metaphoric; and Cognitive Linguists nowadays have been paying more attention to what concepts are (BOLOGNESE; STEEN, 2019; BOLOGNESE et al., 2020). In this vein, we propose that applied linguistics can also contribute to developments in the understanding of concepts by studying conceptualizations, not only as instantiated by frames and metaphors, but also by further specifying differences in concepts.

In this paper, we first introduced research in grounded cognition about concrete and abstract concepts and emphasized some important ideas that may be of interest to applied cognitive linguistics, namely, (i) the theoretical trend towards multiple representations and the dynamic nature of concepts, which are perspectives that allows for the possibility that different data might need to be analyzed according to different theoretical constructs; (ii) the theoretical and empirical recent discussions that suggest that there are some inconsistencies between theories and empirical findings in the classic literature of cognitive linguistics - we suggested that understanding that abstract concepts are not mostly metaphoric opens up analytical possibilities based on the construct of "concepts"; and (iii) the Hebbian principle, proposed by cognitive neuroscience, may point, in general, to what aspects of experience can be expected to form a concept, frame, or metaphor.

Moreover, we emphasized that there is no reason to analyze data in the wild from one unique theoretical perspective unless the aim is to support that theory. Multiple representational and dynamic perspectives about cognition open the possibility for flexible analysis of data and it changes one very important aspect of our research: we cannot make general claims by default, as previous

\footnotetext{
${ }^{13}$ In FrameNet, the compound expression "Alzheimer's disease" is embedded in the frame of Disease, indicating that it is a subset of the broader frame of disease. But we do not know how this expression is in fact processed, because knowledge about compound expressions is more than the sum of their isolated components (Alzheimer + disease).
} 
theories used to make; often, we may have to specify a scope to our claims, considering to what groups of people and/or to what conditions our claims apply. An individual's conceptual system is complex, not to mention many people's conceptual systems or conceptualizations of an issue.

In short, the purpose of this paper is much less to offer guidelines for novel studies in cognitive linguistics, than to highlight interdisciplinary topics that can motivate new research and new perspectives that can foster the dialogue between disciplines and strengthen applied analyzes. Language analyses in the wild do not need to be tied to theories of Cognitive Linguistics - given also that they are contested or contestable theories (GIBBS, 2001; GIBBS, 2017; MCGLONE, 2007, among others).

Thus, considering also that theories, models, and paradigms may change over time, which is quite a general assumption, the conclusion we get from the analysis presented in this text is the following: cognitive linguists could resort to what is currently discussed in cognitive science for better justifying theoretical decisions, especially when theories may cover very broad patterns, and data may carry some eccentricities.

\section{REFERENCES}

AMSEL, B. D.; URBACH, T. P.; KUTAS, M. Empirically grounding grounded cognition: The case of color. Neuroimage, v. 99, p. $149-157,2014$.

ANTONUCCI, S. M.; ALT, M. A lifespan perspective on semantic processing of concrete concepts: does a sensory/motor model have the potential to bridge the gap? Cognitive, Affective, \& Behavioral Neuroscience, v. 11, n. 4, p. 551-572, 2011.

BARROS-LOSCERTALES, A. et al. Reading salt activates gustatory brain regions: fMRI evidence for semantic grounding in a novel sensory modality. Cerebral Cortex, v. 22, n. 11, p. 2554-2563, 2012.

BARSALOU, L. W. Challenges, and Opportunities for Grounding Cognition. Journal of Cognition (in press), 2020.

BARSALOU, L. W.; DUTRIAUX, L.; SCHEEPERS, C. Moving beyond the distinction between concrete and abstract concepts. Philosophical Transactions of the Royal Society B: Biological Sciences, v. 373, n. 1752, p. 20170144, 2018.

BARSALOU, L. W. On staying grounded and avoiding quixotic dead ends. Psychonomic Bulletin \& Review, v. 23, n. 4, p. 1122-1142, 2016.

BARSALOU, L. W. Grounding knowledge in the brain's modal systems. In: UK COGNITIVE LINGUISTICS CONFERENCE. 4., 2012.p. 3 .

BARSALOU, L. W. The human conceptual system. In: SPIVEY, M.; MCRAY, K. The Cambridge Handbook of Psycholinguistics. Cambridge University Press, 2012. p 239-258.

BARSALOU, L. W. Grounded cognition: Past, present, and future. Topics in cognitive science, v. 2, n. 4, p. 716-724, 2010.

BARSALOU, L. W. Grounded cognition. Annu. Rev. Psychol., v. 59, p. 617-645, 2008.

BARSALOU, L. W.; WIEMER-HASTINGS, K. Situating abstract concepts. Grounding cognition: The role of perception and action in memory, language, and thought, p. 129-163, 2005. 
BARSALOU, L. W. Perceptions of perceptual symbols. Behavioral and brain sciences, v. 22, n. 4, p. 637-660, 1999. Available in: https://doi.org/10.1017/S0140525X99002149.

Access in: sept. 2020.

BEHUNIAK, S. M. The living dead? The construction of people with Alzheimer's disease as zombies. Ageing \& Society, v. 31, n. 1, p. 70-92, 2011.

BERGEN, B. K. Louder than words: The new science of how the mind makes meaning.New York: Basic Books (AZ), 2012.

BOLOGNESI, M.; BURGERS, C.; CASELLI, T. On abstraction: decoupling conceptual concreteness and categorical specificity. Cognitive Processing, p. 1-17, 2020.

BOlOGNESI, M.; STEEN, G. Abstract Concepts: Structure, Processing, and Modeling. In: Perspectives on abstract concepts. Amsterdam: John Benjamins Publishing Company, p. 1-13, 2019.

BORGHI, A. M. et al. Varieties of abstract concepts: development, use and representation in the brain. Phil. Trans. R. Soc. 2018. Available in: http://dx.doi.org/10.1098/rstb.2017.0121. Access in: sept. 2020.

BORTFELD, H.; MCGLONE, M. S. The continuum of metaphor processing. Metaphor and Symbol, v. 16, n. 1-2, p. 75-86, 2001.

BUNDGAARD, P. F. The structure of our concepts: A critical assessment of Conceptual Metaphor Theory as a theory of concepts. Cognitive Semiotics, v. 12, n. 1, p. 1-11, 2019.

BUNDGAARD, P. F. Are cross-domain mappings psychologically deep, but conceptually shallow? What is still left to test for conceptual metaphor theory. Cognitive Semiotics, v. 5, n. 1-2, p. 400-407, 2013.

CIPORA, K. et al. A Minority pulls the sample mean: on the individual prevalence of robust group-level cognitive phenomena the instance of the SNARC effect. PsyArXiv, 2019. Available in: https://doi.org/10.31234/osf.io/bwyr3. Access in: sept. 2020.

CHOMSKY, N. Syntactic structures, The Hague: Mouton, 1957.

CROFT, W.; CRUISE, D. A. Cognitive linguistics. United Kingdom: Cambridge University Press, 2004.

CRUTCH, S. J.; WARRINGTON, E. K. Abstract and concrete concepts have structurally different representational frameworks. Brain, v. 128, n. 3, p. 615-627, 2005.

CUCCIO, V.; GALLESE, V. A Peircean account of concepts: grounding abstraction in phylogeny through a comparative neuroscientific perspective. Philosophical Transactions of the Royal Society B: Biological Sciences, v. 373, n. 1752, p. $20170128,2018$.

DAVIS, C. P.; ALTMANN, G. T. M; YEE, E. Situational systematicity: A role for schema in understanding the differences between abstract and concrete concepts. Cognitive Neuropsychology, p. 1-12, 2020.

DEL PRADO MARTÍN, F. M; HAUK, O.; PULVERMÜLLER, F. Category specificity in the processing of color-related and formrelated words: An ERP study. Neuroimage, v. 29, n. 1, p. 29-37, 2006. 
DESAI, R. H.; REILLY, M.; VAN DAM, W. The multifaceted abstract brain. Philosophical Transactions of the Royal Society B: Biological Sciences, v. 373, n. 1752, p. 20170122, 2018.

DI PAOLO, E. A.; CUFFARI, E. C.; DE JAEGHER, H. Linguistic bodies: The continuity between life and language. Massachusetts: Mit Press, 2018.

FELDMAN, J. From molecule to metaphor: A neural theory of language. Massachusetts: MIT Press, 2006.

FIGUEIREDO, N. M.; SIMAN, J H. Questões atuais sobre corpo e linguagem: cognição corporificada, agenda empírica e enativismo linguístico. Conjectura: filosofia e educação, v. 25, 2020 (forthcoming).

FlUSBERG, S. J.; MATLOCK, T.; THIBODEAU, P. H. War metaphors in public discourse. Metaphor and Symbol, v. 33, n. 1, p. 1$18,2018$.

FODOR, J. A. The language of thought. Massachusetts: Harvard University Press, 1975.

FRAME INDEX. 2020. Disponível em: https://framenet2.icsi.berkeley.edu/fnReports/data/frameIndex.xml?frame=Sharing. Access in: sept. 2020.

GALETZKA, C. The story so far: how embodied cognition advances our understanding of meaning-making. Frontiers in Psychology, v. 8, p. 1315, 2017.

GALLESE, V.; LAKOFF, G. The brain's concepts: The role of the sensory-motor system in conceptual knowledge. Cognitive neuropsychology 22, n. 3-4, p. 455-479, 2005.

GARCÍA, A. M. et al. How meaning unfolds in neural time: Embodied reactivations can precede multimodal semantic effects during language processing. NeuroImage, v. 197, p. 439-449, 2019.

GARCÍA, A. M.; IBÁÑEZ, A. A touch with words: dynamic synergies between manual actions and language. Neuroscience \& Biobehavioral Reviews, v. 68, p. 59-95, 2016.

GEORGE, D. R.; WHITEHOUSE, P. J. The war (on terror) on Alzheimer's. Dementia, v. 13, n. 1, p. 120-130, 2014.

GIBBS JR, R.. Making good psychology out of blending theory. Cognitive linguistics, v. 11, p. 347-358, 2001.

GIBBS JR, R. W. The real complexities of psycholinguistic research on metaphor. Language Sciences, v. 40, p. 45-52, 2013.

GIBBS JR, R. W. Metaphor wars. Cambridge: Cambridge University Press, 2017.

GIBBS JR, R.. W. Metaphor as dynamical-ecological performance. Metaphor and Symbol, v. 34, n. 1, p. 33-44, 2019.

GLENBERG, A. M. et al. Processing abstract language modulates motor system activity. The Quarterly Journal of Experimental Psychology, v. 61, n. 6, p. 905-919, 2008.

GOLDINGER, S. D. et al. The poverty of embodied cognition. Psychonomic bulletin \& review, v. 23, n. 4, p. 959-978, 2016. 
GONZÁLEZ, J. et al. Reading cinnamon activates olfactory brain regions. Neuroimage, v. 32, n. 2, p. 906-912, 2006.

GRADY, J. Foundations of Meaning: primary metaphors and primary scenes. Tese (Doutorado em Linguística), University of California, Berkeley, 1997.

HOLYOAK, K. J.; STAMENKOVIĆ, D. Metaphor comprehension: A critical review of theories and evidence. Psychological bulletin, v. 144 , n. 6 , p. 641,2018

IJZERMAN, H. et al. The Human Penguin Project: Climate, Social Integration, and Core Body Temperature. Collabra: Psychology, v.4, n.1, p. 37. 2018. Available in: http://doi.org/10.1525/collabra.165. Access in: sept. 2020.

KIEFER, M. et al. The sound of concepts: Four markers for a link between auditory and conceptual brain systems. Journal of Neuroscience, v. 28, n. 47, p. 12224-12230, 2008.

KÖVECSES, Z. Metaphor and emotion. New York: Oxford University Press. 2000.

KÖVECSES, Z.; PALMER, G. B.; DIRVEN, R. Language and emotion: The interplay of conceptualisation with physiology and culture. In: Metaphor and metonymy in comparison and contrast, Berlim: De Gruyter Mouton, 2003, p. 133-159.

KÖVECSES, Z. Some consequences of a multi-level view of metaphor. Current approaches to metaphor analysis in discourse, v., p. 19-33, 2019.

LAKOFF, G.; JOHNSON, M. Metaphors we live by. Chicago, IL: University of Chicago, 1980.

LAKOFF, G. How metaphor structures dreams: The theory of conceptual metaphor applied to dream analysis. Dreaming, v. 3, n. 2 , p.77, 1992.

LAKOFF, G; JOHNSON, M. Philosophy in the flesh: The embodied mind and its challenge to western thought. New York: Basic books, 1999.

LAKOFF, G. The neural theory of metaphor. In: GIBBS, R. W. (ed). The Cambridge Handbook of Metaphor and Thought. Cambridge University Press, 2008. p. 17-38.

LANE, H. P.; MCLACHLAN, S.; PHILIP, J. The war against dementia: are we battle weary yet?. Age and ageing, v. 42, n. 3, p. 281$283,2013$.

LESHINSKAYA, A.; CARAMAZZA, A. For a cognitive neuroscience of concepts: Moving beyond the grounding issue. Psychonomic bulletin \& review, v. 23, n. 4, p. 991-1001, 2016.

MAHON, B. Z. The burden of embodied cognition. Canadian Journal of Experimental Psychology/Revue canadienne de psychologie expérimentale, v. 69, n. 2, p. 172, 2015.

MARTIN, A.; CHAO, L. L. Semantic memory and the brain: structure and processes. Current opinion in neurobiology, v. 11, n. 2, p. 194-201, 2001. 
MARTIN, A. The representation of object concepts in the brain. Annu. Rev. Psychol., v. 58, p. 25-45, 2007.

MARTINS, S. A Doença de Alzheimer e suas manifestações na linguagem: um estudo sobre a divulgação científica brasileira e norteamericana à luz da Linguística Cognitiva. 2019. Tese (Doutorado em Linguística) - Faculdade de Letras, Universidade Federal de Minas Gerais, Belo Horizonte, 2019.

MCGLONE, M. S. What is the explanatory value of a conceptual metaphor?. Language \& Communication, v. 27, n. 2, p. 109-126, 2007.

MITCHELL, M. Complexity: A guided tour. Oxford University Press, 2009.

NGATCHA-RIBERT, L. Alzheimer disease and society: an analysis of its social representation. Psychologie \& neuropsychiatrie du vieillissement, v.2, n.1, p. 49-66, 2004.

ONNIS, L.; SPIVEY, M. J. Toward a new scientific visualization for the language sciences. Information, v. 3, n. 1, p. $124-150,2012$.

PAIVIO, A. Mental representations: A dual coding approach. Oxford University Press, 1986.

PECHER, D.; ZEELENBERG, R.; BARSALOU, L. W. Sensorimotor simulations underlie conceptual representations: Modalityspecific effects of prior activation. Psychonomic Bulletin \& Review, v. 11, n. 1, p. 164-167, 2004.

PULVERMÜLLER, F. Neural reuse of action perception circuits for language, concepts and communication. Progress in neurobiology, v. 160, p. 1-44, 2018.

PULVERMÜLLER, F. How neurons make meaning: brain mechanisms for embodied and abstract-symbolic semantics. Trends in cognitive sciences, v. 17, n. 9, p. 458-470, 2013.

PULVERMÜLLER, F; FADIGA, L. Active perception: sensorimotor circuits as a cortical basis for language. Nature reviews neuroscience, v. 11, n. 5, p. 351-360, 2010.

PULVERMÜLLER, F. Brain mechanisms linking language and action. Nature reviews neuroscience, v. 6, n. 7, p. 576-582, 2005.

ROTH, M. A. Representation, philosophical issues about. Wiley Interdisciplinary Reviews: Cognitive Science, v. 1, n. 1, p. 32-39, 2010.

SAUCIUC, G-A.. The role of metaphor in the structuring of emotion concepts. Cognitive Semiotics, v. 5, n. 1-2, p. 244-267, 2009.

SEMINO, E.; DEMJÉN, Z.; DEMMEN, J. An integrated approach to metaphor and framing in cognition, discourse, and practice, with an application to metaphors for cancer. Applied Linguistics, v. 39, n. 5, p. 625-645, 2016.

SIMAN, J. H. Os frames de Doença de Alzheimer. 2015. Dissertação (mestrado em Linguística) Universidade Estadual de Campinas, Campinas, 2015.

SIMAN, J. H. Metáforas sobre doença de alzheimer: no pensamento e no mundo social. Revista do SETA, v. 9, p.1-19, 2019.

SPIVEY, M. The continuity of mind.Oxford Local: Oxford University Press, 2006. 
STEEN, G. Deliberate Metaphor Theory: Basic assumptions, main tenets, urgent issues. Intercultural Pragmatics, v. 14, n. 1, p. 1-24, 2017.

THIBODEAU, P. H.; BORODITSKY, L. Metaphors we think with: The role of metaphor in reasoning. PloS one, v. 6, n. 2, p.1-11, 2011.

TOMASELLO, R. et al. Brain connections of words, perceptions and actions: A neurobiological model of spatio-temporal semantic activation in the human cortex. Neuropsychologia, v. 98, p. 111-129, 2017.

VARELA, F. J.; THOMPSON, E.; ROSCH, E. The embodied mind: Cognitive science and human experience. Massachusetts: MIT Press, 2016

VAN GORP, B.; VERCRUYSSE, T. Frames and counter-frames giving meaning to dementia: a framing analysis of media content. Social Science \& Medicine, v.8, n. 74, p. 1274-1281, 2012.

\section{๑(1) $\ominus$}

Received in Juin 2, 2020. Approved in October 8, 2020. 